\title{
The influence of substrates and physicochemical factors on the composition of diatom assemblages in karst springs and their applicability in water-quality assessment
}

\author{
Agata Z. Wojtal $\cdot$ Lukasz Sobczyk
}

Received: 17 January 2010/ Accepted: 6 April 2011/Published online: 22 June 2012

(C) The Author(s) 2012. This article is published with open access at Springerlink.com

\begin{abstract}
The methodological standards of monitoring programs recommend collecting material from stones, but this community is often absent in slowflowing waters, whereas a great number of localities do offer bryophytic material for sampling. In order to investigate whether the kind of substrate (epilithic or bryophytic) influences the diatom-based biomonitoring results the structure of diatom assemblages from 13 anthropogenically altered springs were investigated. To examine differences between diatom assemblages, the species richness of diatom assemblages, $H^{\prime}$ (Shannon-Wiener diversity index), Trophic Diatom Index (TDI) and Specific Pollution sensitivity Index (SPI) were compared. The TDI and SPI differed significantly $(P=0.002$ and $P=0.004)$ between springs located in villages and springs away from villages, and did not differ significantly between epilithic and bryophytic samples $(P>0.05)$. No
\end{abstract}

Guest editors: L. Ector, D. Hlúbiková \& L. Hoffmann / Proceedings of the 7th International Symposium "Use of Algae for Monitoring Rivers", Luxembourg, November 23-25, 2009

A. Z. Wojtal $(\bowtie)$

Department of Phycology, W. Szafer Institute of Botany, Polish Academy of Sciences, Lubicz 46, 31-512 Kraków, Poland

e-mail: a.wojtal@botany.pl

Ł. Sobczyk

Institute of Environmental Sciences, Jagiellonian University, Gronostajowa 7, 30-387 Kraków, Poland significant differences in species richness or the diversity index $\left(H^{\prime}\right)(P>0.05)$ were found between the epilithic and bryophytic diatom assemblages. This study suggests that both the kinds of substrates can be successfully used for diatom-based water-quality biomonitoring in mesotrophic and eutrophic environments.

Keywords Bioindication - Diatoms - Epibryon · Epilithon · Krakowsko-Częstochowska Upland . Nutrients

\section{Introduction}

Diatoms are one of the most commonly used organisms for assessing natural and human-related features of aquatic environments. Their value as bioindicators was appreciated long ago, and diatom analysis is still done for reconstruction of the paleoenvironment and for water quality/environmental health assessment. Their usefulness is due to the quick and precise response of the diatom assemblage structure to changing conditions (Stoermer \& Smol, 1999). To standardize the methodology of using diatoms for water-quality assessment and to minimize substraterelated variability of diatom assemblage structure, it has been recommended to study communities developing on a single type of substrate; for example, in analyses of running waters the epilithon is recommended (e.g. Round, 1991, 1993; Kelly et al., 1998; Townsend \& Gell, 2005). 
Once the general regularities of how specific diatom assemblages form in response to $\mathrm{pH}$, salinity, trophic state and several other physicochemical parameters were recognized, a number of detailed studies of habitat-diatom assemblage relationships were undertaken. The relationships between benthic communities and substrate type have been the subject of several investigations and extensive discussion (Douglas, 1958; Stevenson \& Hashim, 1989; Jüttner et al., 1996; Rothfritz et al., 1997; Sabater et al., 1998; Potapova \& Charles, 2005; Townsend \& Gell, 2005; Cantonati \& Spitale, 2009). As the relationships between substrate and the organisms inhabiting it are much more complicated in benthic and periphytic communities (Cox, 1990; Burkholder, 1996; Townsend \& Gell, 2005) than in plankton, the effects of different factors on assemblage structure in running waters are much less well understood. The influence of biotic and abiotic substrates on diatom assemblages has been studied in rivers on broad geographical scales (e.g. Jüttner et al., 1996; Rothfritz et al., 1997; Potapova \& Charles, 2005; Townsend \& Gell, 2005) but has received much less attention in springs (Cantonati, 2001; Cantonati \& Spitale, 2009). Springs provide excellent opportunities for such studies because the fluctuation of water properties is minimal (Sabater \& Roca, 1990; Cantonati et al., 2006; Dumnicka et al., 2007; Cantonati \& Spitale, 2009) and the input of allochthonous organisms from other environments is limited. The available data indicate that the geomorphological features of an area and the water characteristics are major factors governing the diatom distribution in springs (Werum, 2001; Werum \& Lange-Bertalot, 2004; Cantonati et al., 2006).

Most of the data on diatoms in springs come from mountain areas in natural or near-natural conditions (Sabater \& Roca, 1990, 1992; Cantonati, 1998; Battegazzore et al., 2004; Werum \& Lange-Bertalot, 2004), where the epilithon generally occurs. In lowland areas, the role of epilithic communities is smaller, because slow flow allows sediment to accumulate and become the predominant substrate in springs, together with submerged vascular and nonvascular macrophytes. Macrophytes such as bryophytes occur in most springs and are one of the most common habitats for a very diverse microflora (Cantonati \& Spitale, 2009; Hájkova et al., 2011). A comparison of the structure of diatom assemblages in bryophytic and epilithic communities from non-mountain, mesotrophic springs can provide applicative data to use for water-quality biomonitoring; epilithic assemblages are recommended for waterquality assessment, but such assemblages are virtually absent in several aquatic lowland systems (e.g. Potapova \& Charles, 2005). In order to investigate whether the kind of substrate (epilithic or bryophytic) commonly used for assessment of water quality diatom influences, e.g. Trophic Diatom Index (TDI; Kelly \& Whitton, 1995) and Specific Pollution sensitivity Index (SPI; CEMAGREF, 1982), the diatom assemblages from 13 anthropogenically altered springs were investigated.

\section{Site description}

The springs in question are situated in the Wyżyna Krakowsko-Częstochowska Upland in southern Poland (Table 1). This upland, covering $2,650 \mathrm{~km}^{2}$, extends from the Carpathian foothills in the vicinity of Kraków northward to the town of Częstochowa. It is ca. $80-\mathrm{km}$ long and ca. $20-\mathrm{km}$ wide, and rises to $350 \mathrm{~m}$ a.s.l. on average. Geologically, it is karst formed in Upper Jurassic calcareous rock up to 200-m thick and further altered since the Cretaceous (Różkowski, 1996), partly covered by Quaternary loess in the southern part and by postglacial sands in the northern part (Dynowska, 1983). Most of the spring water belongs to the bi-ionic $\mathrm{HCO}_{3}{ }^{-} \mathrm{Ca}^{2+}$ category. Local hydrogeology is the main natural factor determining the spatial diversity of spring water chemistry (Siwek, 2004). The springs from the southern part of the upland are supplied from the Jurassic aquifer and are typically small, with discharge between 0.4 and $151 \mathrm{~s}^{-1}$ (Dumnicka et al., 2007). Rapid circulation in a shallow system of large karstic channels limits bedrock weathering there. The northern part of the study area belongs to the Cretaceous aquifer, and the springs supplied by it have greater discharge. The range of spring water chemistry is much broader there, due to diverse geology, several local water tables, and higher mineral dissolution of the bedrock (Siwek, 2004). The springs of the Krakowsko-Częstochowska Upland are very vulnerable to pollution because surface water flows rapidly into groundwater systems through natural conduits and is under significant anthropogenic pressure. Most of the springs in this study are located in highly populated areas. The selected springs differ in 
discharge, type of surroundings, degree of artificial modification and ionic composition (Tables 1,2).

\section{Methods}

Epilithic, bryophytic samples and water for physical and chemical analyses were collected in SeptemberNovember 2004. Composite samples of at least four subsamples from submerged stones were collected by brushing the upper surface of submerged stones and squeezing from submerged bryophytes. Although previous studies did not show essential differences in the structure of epilithic diatom associations on stones of differing size in slow-flowing waters (Wojtal \& Sobczyk, 2006), we collected the epilithon samples from stones of similar size. Some of the environmental variables were measured at the time of diatom sampling. Water temperature was taken and specific conductivity and $\mathrm{pH}$ were measured using an Elmetron CC-102 conductivity metre and a CC-104 pH metre. Other chemistry data were obtained by ion chromatography (Dionex 100), atomic absorption spectrophotometry and flame AAS in the Institute of Botany laboratory in Szarów, Poland.

To remove carbonates, $10 \% \mathrm{HCl}$ was added to the samples in 250-ml glass beakers and boiled for $15 \mathrm{~min}$ after $24 \mathrm{~h}$. Then the material was washed at least five times with distilled water, with $24 \mathrm{~h}$ settling time between each decanting. Then the samples were boiled in $30 \% \mathrm{H}_{2} \mathrm{O}_{2}$ with small amounts of $\mathrm{KClO}_{3}$, or using concentrated $(>30 \%)$ acids $\left(\mathrm{H}_{2} \mathrm{SO}_{4}, \mathrm{HNO}_{3}\right)$ to remove any leftover organic matter not digested by peroxide. After washing several times with distilled water the material was air dried on coverglasses and mounted in Naphrax ${ }^{\circledR}$ resin. The diatoms were observed with a Nikon Eclipse 600 light microscope with Differential Interference Contrast.

The relative abundance of particular taxa and the species richness of the assemblages were estimated on the basis of at least 300 diatom valves per sample. To examine differences between diatom assemblages, we compared the species richness of epilithic and bryophytic assemblages, and the following indices for assessing water quality were computed with Omnidia 4.1 software (Lecointe et al., 1993): $H^{\prime}$ (ShannonWiener diversity index), TDI and SPI.

Differences in Shannon-Wiener diversity index, TDI and SPI between bryophytic samples and epilithic

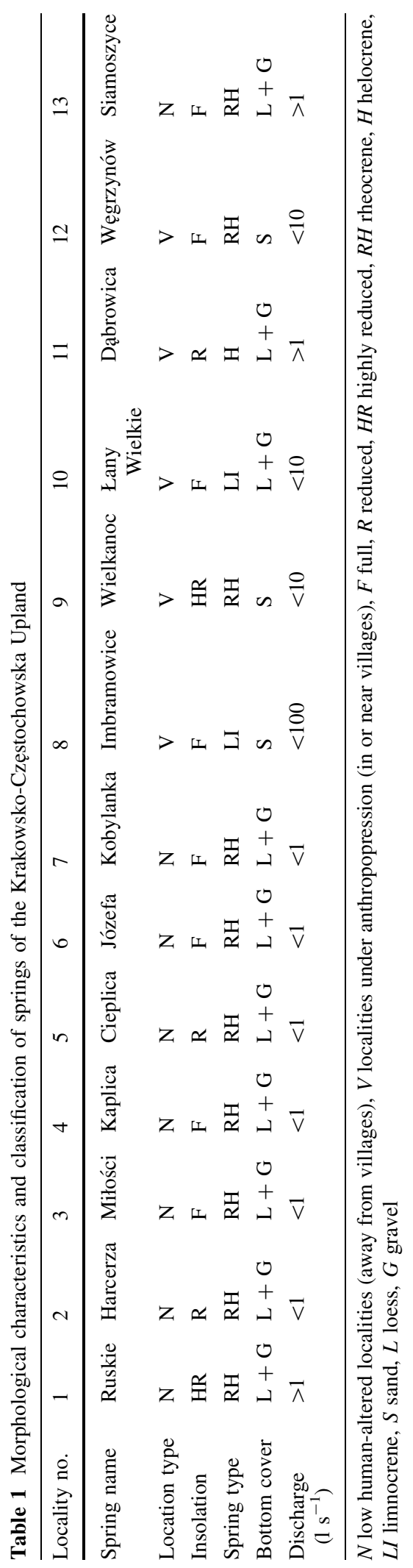




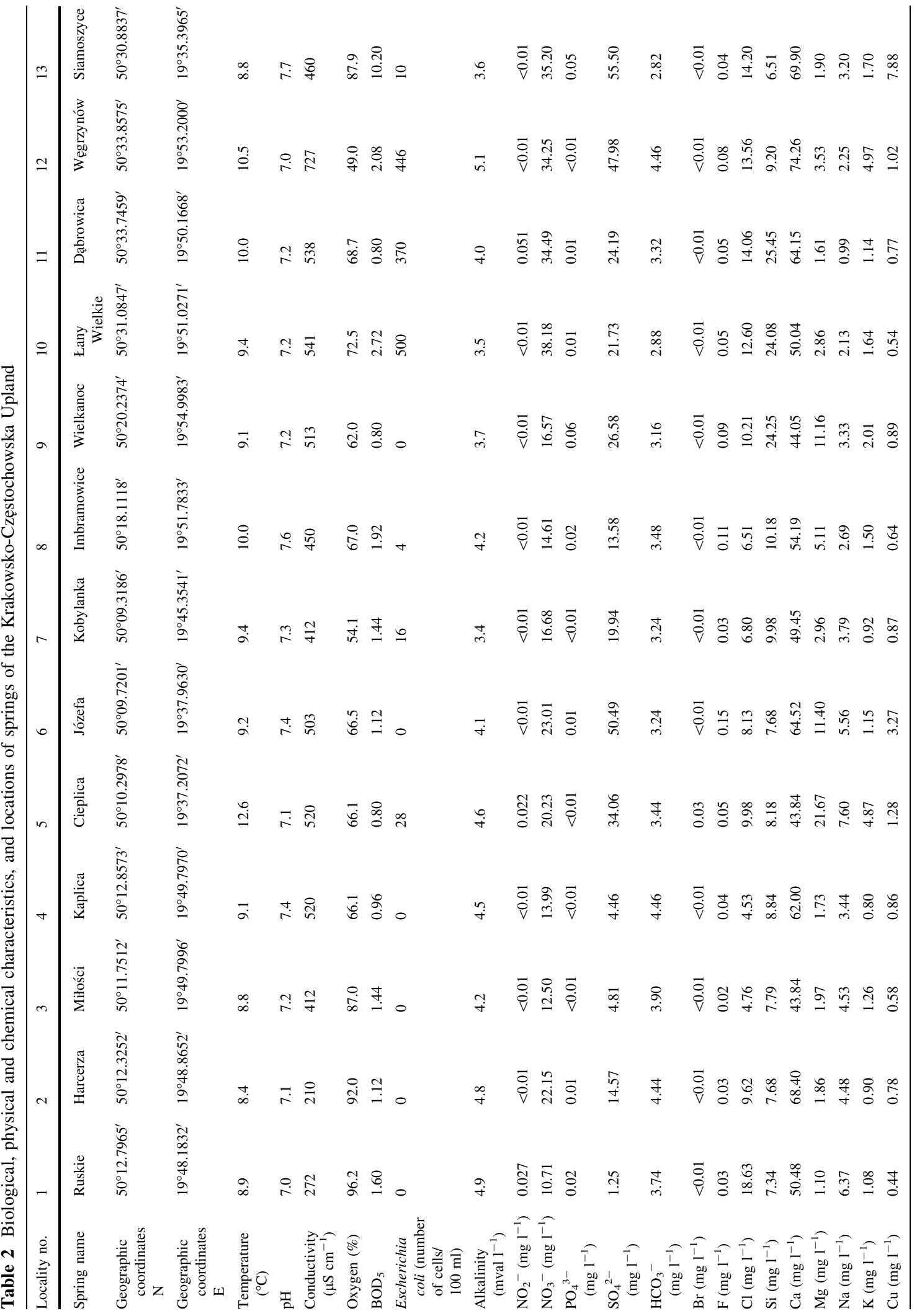


samples and between springs under anthropogenic pressure (in or near villages) and springs away from villages were analyzed using ANOVA with three factors: substrate, spring and location type and springs nested in location type. Taxa accounting for $>1 \%$ of the diatom assemblages at more than three of the studied springs, after logarithmic transformation (natural logarithm) were included in the ordination analyses. To explain variability in the species composition the data were analyzed by principal correspondence analysis (PCA) using correlation matrix. To explain species-environment relationship the species data were analyzed by redundancy analysis (RDA) (CANOCO v4.5 software; ter Braak \& Šmilauer, 2002; Lepš \& Šmilauer, 2003). The analyses were performed using the whole data set (bryophytic and epilithic diatom assemblages together) and then separately for bryophytic diatom assemblages only and epilithic diatom assemblages only.

\section{Results}

The $\mathrm{pH}$ range was $<1 \mathrm{U}(\mathrm{pH}$ 7.0-7.7) for the whole data set. All analyzed localities showed comparable calcium concentration, alkalinity and temperature (Table 2). There was a relatively high variation of specific conductivity in the springs, ranging from 210 (Harcerza spring) to $727 \mu \mathrm{S} \mathrm{cm}^{-1}$ (spring in Węgrzynów), and considerable variation of nitrate concentration from 10.7 (Ruskie spring) to $38.2 \mathrm{mg}^{-1}$ (spring in Łany Wielkie). The diatom assemblages were dominated by neutrophilous and alkaliphilous, mesotraphentic and eutraphentic, $\alpha$ - and $\beta$-mesosaprobous diatoms (Table 3).

We identified a total of 136 diatom taxa, the vast majority of which were typically epilithic or typically epiphytic forms. Only 17 were common (i.e. present at $>10 \%$ relative abundance in at least one sample); of those, 10 reached $>20 \%$ relative abundance in at least one sample. Average species richness in epilithic samples was 18 diatom taxa, ranging from 5 to 34; the corresponding figures for bryophytic samples are 18.5 and 12-29. Average species richness differed between southern (away from villages; less eutrophicated) and northern (in or near villages; more eutrophicated) waters: 24 and 12, respectively, in the epilithon, and 19 and 18 in bryophytic samples. The ShannonWiener diversity index $\left(H^{\prime}\right)$ did not differ significantly 
Table 3 Shannon-Wiener diversity index $\left(H^{\prime}\right)$, trophic, saprobic and dissolved oxygen limit tolerances, pH preferences, and TDI and SPI index values calculated for diatom assemblages using Omnidia software

\begin{tabular}{|c|c|c|c|c|c|c|c|c|c|c|c|c|c|}
\hline Locality no. and type of sample & $1 \mathrm{E}$ & 1B & $2 \mathrm{E}$ & 2B & $3 \mathrm{E}$ & 3B & $4 \mathrm{E}$ & $4 \mathrm{~B}$ & $5 \mathrm{E}$ & $5 \mathrm{~B}$ & $6 \mathrm{E}$ & $6 \mathrm{~B}$ & $7 \mathrm{E}$ \\
\hline$H^{\prime}$ & 3.7 & 2.5 & 3.7 & 2.2 & 3.3 & 2.6 & 2.1 & 2.5 & 2.4 & 2.6 & 2.3 & 2.5 & 3.3 \\
\hline Trophic tolerances & m-e & $\mathrm{m}$ & $\mathrm{e}$ & ind & $\mathrm{e}$ & ind & o & ind & $\mathrm{e}$ & ind & ind & e & $\mathrm{m}-\mathrm{e}$ \\
\hline Saprobic tolerances & $\beta$-m & $\beta$-m & $\beta-\mathrm{m}$ & $\beta-\mathrm{m}$ & $\beta-\mathrm{m}$ & $\beta-\mathrm{m}$ & mes & $\beta-\mathrm{m}$ & $\beta-\mathrm{m}$ & $\beta-\mathrm{m}$ & $\beta$-m & $\beta-\mathrm{m}$ & $\beta-\mathrm{m}$ \\
\hline Oxygen limit tolerances $(\%)$ & 50 & 50 & 75 & 50 & 100 & 100 & 100 & 75 & 100 & 100 & 100 & 50 & 100 \\
\hline $\mathrm{pH}$ preferences & alk & alk & alk & alk & alk & alk & alk & alk & neut & alk & neut & alk & alk \\
\hline TDI & 55.8 & 59 & 63 & 57 & 41.2 & 50 & 30 & 41.7 & 46 & 54 & 44 & 52 & 55.1 \\
\hline IPS & 18 & 16 & 17 & 16 & 18 & 18 & 19 & 19 & 18 & 18 & 19 & 18 & 18.5 \\
\hline Locality no. and type of sample & $7 \mathrm{~B}$ & $8 \mathrm{E}$ & $8 B$ & $9 \mathrm{E}$ & $9 B$ & $10 \mathrm{E}$ & $10 \mathrm{~B}$ & $11 \mathrm{E}$ & $11 \mathrm{~B}$ & $12 \mathrm{E}$ & $12 \mathrm{~B}$ & $13 \mathrm{E}$ & $13 \mathrm{~B}$ \\
\hline$H^{\prime}$ & 3.8 & 1.6 & 1.6 & 0.9 & 1.7 & 2.6 & 1.6 & 2.9 & 3.7 & 2.8 & 2.7 & 3.1 & 3.1 \\
\hline Trophic tolerances & ind & $\mathrm{e}$ & ind & m-e & $\mathrm{e}$ & e & m-e & $\mathrm{m}-\mathrm{e}$ & $\mathrm{e}$ & $\mathrm{e}$ & e & ind & $\mathrm{m}$ \\
\hline Saprobic tolerances & $\beta$-m & $\beta-\mathrm{m}$ & $\beta$-m & $\alpha-\mathrm{m}$ & $\alpha$-mes & $\beta$-m & $\alpha-\mathrm{m}$ & $\beta-\mathrm{m}$ & $\beta-\mathrm{m}$ & $\beta-\mathrm{m}$ & $\beta-\mathrm{m}$ & $\beta-\mathrm{m}$ & $\beta$-m \\
\hline Oxygen limit tolerances (\%) & 75 & 100 & 100 & 50 & 50 & 100 & 50 & 100 & 100 & 100 & 100 & 100 & 100 \\
\hline $\mathrm{pH}$ preferences & alk & alk & alk & alk & alk & neut & alk & alk & alk & alk & alk & alk & alk \\
\hline TDI & 53 & 75 & 97 & 92.6 & 92 & 50 & 70 & 73 & 81 & 81 & 57 & 43 & 68 \\
\hline IPS & 17.5 & 16 & 16 & 18 & 17 & 17 & 18 & 15 & 15 & 17 & 17 & 16.5 & 18 \\
\hline
\end{tabular}

$E$ epilithon, $B$ submerged bryophytes, $o$ oligotraphentic, ind of a broad spectrum of trophic conditions, $m$ mesotraphentic, $m$ - $e$ mesoeutraphentic, $e$ eutraphentic, mes mesosaprobous, $\alpha$ - $m \alpha$-mesosaprobous, $\beta$ - $m \beta$-mesosaprobous, alk alkaliphilous, neut neutrophilous

between these groups, however. The different springs had similar total numbers of species, but the number of rare species $(<1 \%$ relative abundance) shared among all 13 localities was low.

The diatom assemblages in both the bryophytic and the epilithic samples were dominated ( $>20 \%$ relative abundance) by Achnanthidium minutissimum (Kützing) Czarnecki, Amphora pediculus (Kützing) Grunow, Planothidium lanceolatum (Brébisson) Lange-Bertalot, Staurosira venter (Ehrenberg) Grunow and Staurosirella pinnata (Ehrenberg) D.M. Williams \& Round. The diatoms that dominated exclusively in the epilithon were Achnanthidium pyrenaicum (Hustedt) H. Kobayasi, Fragilariforma nitzschioides (Grunow) D.M. Williams \& Round and Reimeria sinuata (W. Gregory) Kociolek \& Stoermer; in bryophytic samples they were replaced by Caloneis fontinalis (Grunow) Lange-Bertalot \& E. Reichardt and Meridion circulare (Greville) C. Agardh. The other common diatoms ( $>10 \%$ relative abundance) were Cocconeis placentula Ehrenberg, Denticula tenuis Kützing, Diatoma mesodon (Ehrenberg) Kützing, Gomphonema micropus Kützing, G. cf. pumilum (Grunow) E. Reichardt \& Lange-Bertalot, Planothidium minutissimum (Krasske) E. Morales and $P$. reichardtii Lange-Bertalot $\&$ Werum. The diatoms reaching $>20 \%$ relative abundance formed $67.3 \%$ of all valves identified in the counts of samples from epilithic substrates, and $74.4 \%$ of those from bryophytic substrates; the respective values increase to 95.8 and $96.0 \%$ when all taxa having over $10 \%$ relative abundance are included. Twenty taxa accounting for $>1 \%$ of the diatom assemblages at more than three of the springs were found in the epilithon, and 13 such species in the epibryon; those species were included in the statistical analyses. The species-locality relationship analysis (PCA) of all the samples revealed that the first two principal components accounted for $18.9 \%$ (axis 1) and $16.1 \%$ (axis 2) of the total variation of species composition (Fig. 1). The first axis separates samples collected from springs situated in or near villages (mainly areas covered by postglacial sands) from those situated in localities less affected by human impacts (mainly loess-covered areas) (Table 1). Axis 2 separates samples collected from epilithic and bryophytic substrates. The main positive contributions to the results were from Caloneis fontinalis, Meridion circulare, Planothidium lanceolatum, Gomphonema cf. pumilum, Diatoma mesodon and Diploneis krammeri LangeBertalot \& E. Reichardt, which were more abundant in bryophytic samples, and Denticula tenuis, Eolimna minima (Grunow) Lange-Bertalot, Staurosirella pinnata, Staurosira venter, Planothidium reichardtii, Achnanthidium 


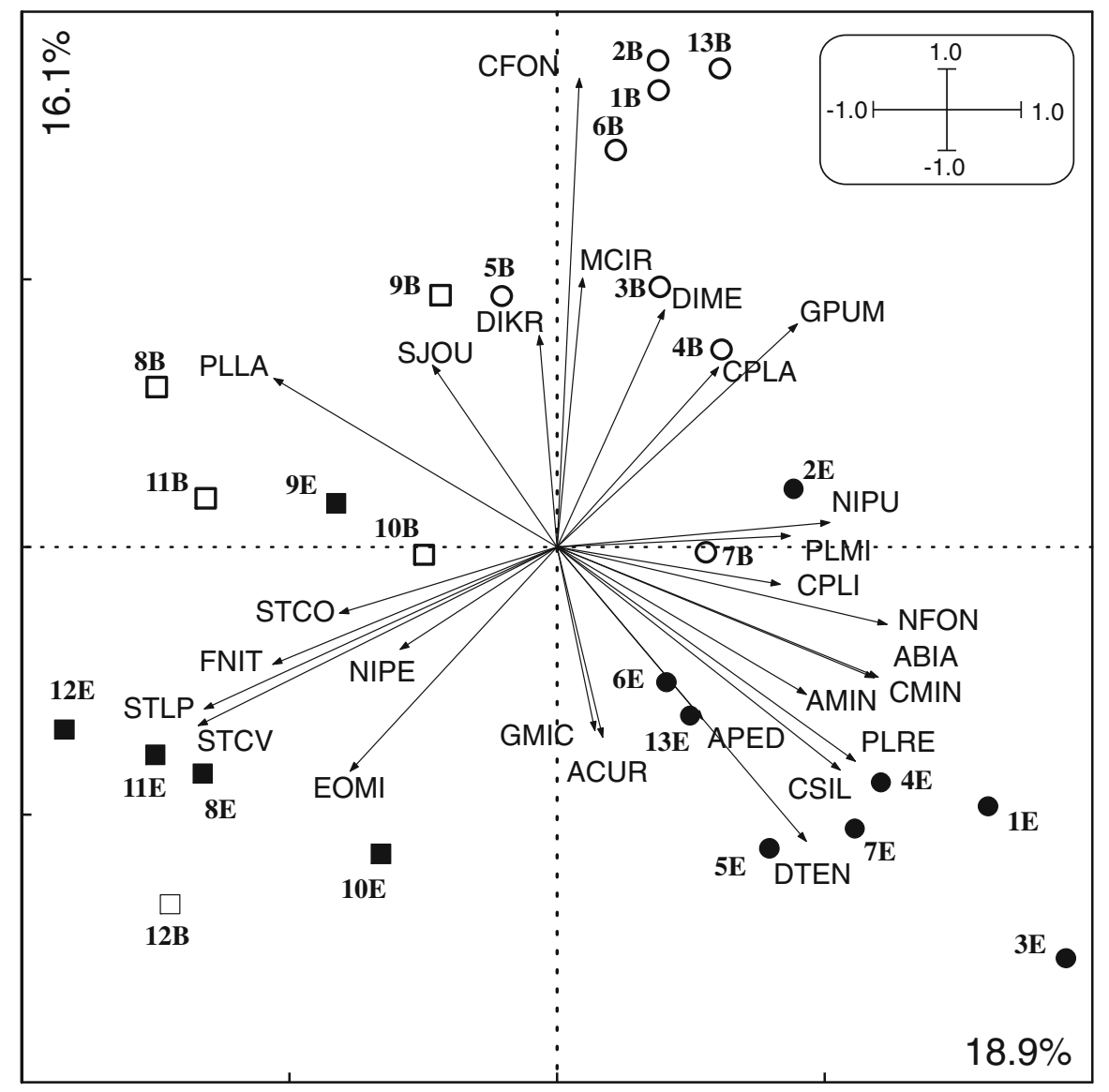

Fig. 1 PCA ordination biplot. The first axis separates samples collected from springs in or near villages from those in less human-altered localities, away from villages. Empty circles Bryophytic samples, filled circles epilithic samples from springs located away from villages, empty squares bryophytic samples, filled squares epilithic samples from springs located in or near villages. Numbers localities. $E$ epilithon, $B$ submerged bryophytes, ABIA A. pyrenaicum, AMIN Achnanthidium minutissimum, ACUR Psammothidium cf. curtissimum (Carter) Aboal, APED Amphora pediculus, CFON Caloneis fontinalis, CMIN Encyonema minutum, CSIL E. silesiacum (Bleisch) D.G. Mann,

pyrenaicum and Gomphonema micropus, which were more numerous in epilithic samples.

RDA based on combined data from epilithic and bryophytic assemblages showed that the first two axes accounted for $24.9 \%$ (axis 1) and $13.5 \%$ (axis 2) of the total variability in the species composition (Fig. 2). More than half of the total variability of the relationship between species composition and environmental variables was explained by the first two axes: $35.0 \%$ by axis 1 and $19.9 \%$ by axis 2 , but these axes were not significant $(P>0.05)$.
CPLA Cocconeis placentula, CPLI C. placentula var. lineata (Ehrenberg) Van Heurck, DIKR D. krammeri, DIME Diatoma mesodon, DTEN Denticula tenuis, EOMI Eolimna minima, FNIT Fragilariforma nitzschioides, GMIC Gomphonema micropus, GPUM G. cf. pumilum, MCIR Meridion circulare, NFON Nitzschia fonticola, NIPE Nitzschia perminuta (Grunow) Peragallo, NIPU N. pura Hustedt, PLLA Planothidium lanceolatum, PLMI P. minutissimum, PLRE P. reichardtii LangeBertalot \& Werum, SJOU Sellaphora joubaudii (H. Germain) Aboal, STCO Staurosira construens Ehrenberg, STCV S. venter, STLP Staurosirella pinnata

In an additional PCA restricted to the bryophytic diatom assemblages the first two principal components accounted for $31.8 \%$ (axis 1) and $21.9 \%$ (axis 2) of the total variation of species composition. RDA for these assemblages showed that the first two axes explain $29.7 \%$ (axis 1) and $9.4 \%$ (axis 2) of variance in species composition and $52.5 \%$ (axis 1) and $\mathbf{1 7 . 6 \%}$ (axis 2) the relationships between species composition and environmental variables. The first axix (RDA) was significant $(P=0.008)$ and correlated positively with dissolved oxygen concentration and negatively 


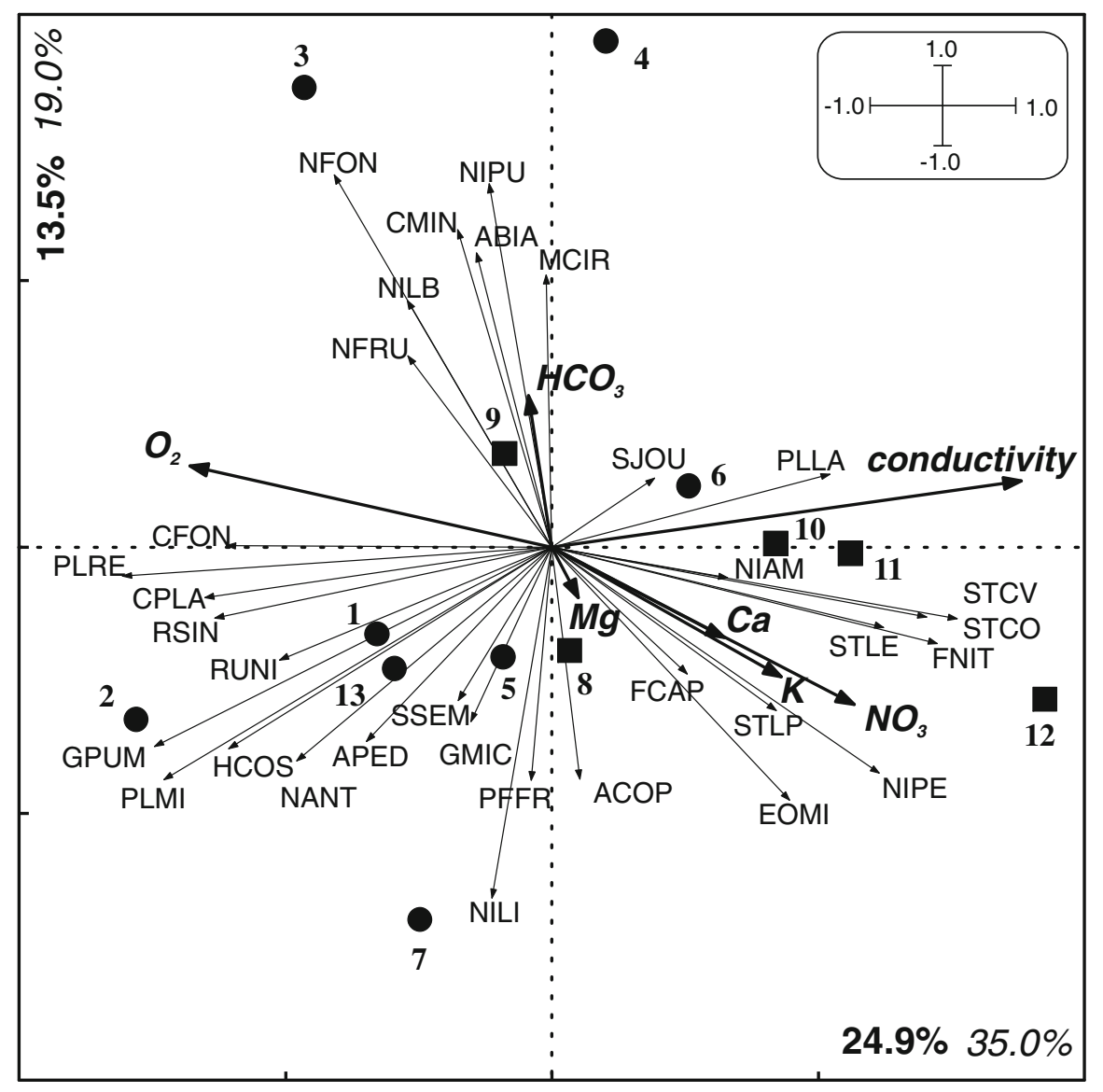

Fig. 2 RDA ordination triplot. Numbers localities. Arrowsspecies and environmental variables. In bold-\% of variance in species composition, in italics-\% of variance in speciesenvironment relationship. ABIA Achnanthidium pyrenaicum, ACOP Amphora copulata, APED A. pediculus, CFON Caloneis fonticola, CMIN Encyonema minutum, CPLA Cocconeis placentula, EOMI Eolimna minima, FCAP Fragilaria capucina, FNIT Fragilariforma nitzschioides, GMIC Gomphonema micropus, GPUM G. cf. pumilum, HCOS Hippodonta costulata (Grunow) Lange-Bertalot, MCIR Meridion circulare, NANT

with specific conductivity and nitrate concentration. The first axis again separated the samples collected from springs with higher dissolved oxygen concentration and lower specific conductivity (Harcerza, Siamoszyce and Ruskie springs), with predominance of Gomphonema cf. pumilum, Caloneis fontinalis, Cocconeis placentula and Diatoma mesodon, which were replaced by Planothidium lanceolatum and Eolimna minima in springs with higher nutrient concentration and higher specific conductivity (in Wegrzynów and Łany Wielkie springs). Higher relative abundance of Staurosirella pinnata was related to springs with sandy
Navicula antonii Lange-Bertalot, NFON Nitzschia fonticola, NIAM N. amphibia Grunow, NFRU N. frustulum (Kützing) Grunow, NILB N. liebetruthii Rabenhorst, NILI N. linearis, NIPE N. permitis, NIPU N. pura, PFFR Planothidium frequentissimum, PLLA P. lanceolatum, PLMI P. minutissimum, PLRE P. reichardtii, RSIN Reimeria sinuata, RUNI $R$. uniseriata Sala, Guerrero \& Ferrario, SJOU Sellaphora joubaudii, SSEM S. seminulum, STCO Staurosira construens, STCV S. venter, STLP Staurosirella pinnata, STLE S. leptostauron (Ehrenberg) D.M. Williams \& Round

bottom and high discharge (e.g. Imbramowice spring); the occurrence of Achnanthidium minutissimum, Meridion circulare and Amphora pediculus was typical of small springs with gravel and silt bottom.

PCA analysis of epilithic diatom assemblages only revealed that the first two principal components accounted for $30.2 \%$ (axis 1) and $15.4 \%$ (axis 2) of the total variation of species composition. RDA for these assemblages showed that the first axes explain $23.3 \%$ (axis 1) and $11.4 \%$ (axis 2) of variation in a structure of diatom assemblages and $37.5 \%$ (axis 1) and $18.3 \%$ (axis 2) in the relationship between species 
composition and environmental factors, but both axes were not significant $(P>0.05)$. The first axis separated samples collected in springs with elevated specific conductivity, high nitrates, sulphates, calcium and orthophosphates, from those less eutrophicated, with higher dissolved oxygen concentration. The largest contribution to separation of the more eutrophicated springs was from Eolimna minima, Planothidium lanceolatum, Staurosirella pinnata and Staurosira venter. The rest of the springs with higher dissolved oxygen and lower specific conductivity were mainly colonized by Achnanthidium minutissimum, Amphora pediculus, Planothidium reichardtii, Cocconeis placentula, Gomphonema cf. pumilum, Encyonema minutum (Hilse) D.G. Mann, Nitzschia fonticola Grunow, Denticula tenuis and Achnanthidium pyrenaicum.

The diatom indices, TDI and SPI, differed significantly $(P=0.002$ and $P=0.004)$ between springs in villages (no. 8-12, Table 1) and springs away from villages (no. 1-7 and 13, Table 1), and did not significantly differ between epilithic and bryophytic samples $(P>0.05)$.

\section{Discussion}

The minimal fluctuation of chemical parameters in springs (Sabater \& Roca, 1990; Cantonati et al., 2006; Dumnicka et al., 2007), as compared to other freshwater systems and especially lakes, is related to the continuous renewal of the aquatic environment in springs. In karst areas, where pollutants are easily transported into the aquifer, spring water chemistry reflects changes in the whole area of the aquifer feeding the springs (Siwek, 2004). The composition of natural spring water is related to natural factors such as the weathering resistance of carbonate rocks, reflected mainly in total mineral content. High nitrate concentrations have been observed in several springs of this upland for decades, and are a permanent feature (Baścik et al., 2001; Siwek, 2004; Wojtal et al., 2009). The increased specific conductivity and $\mathrm{Na}^{+}, \mathrm{Cl}^{-}, \mathrm{K}^{+}$ and $\mathrm{SO}_{4}{ }^{2-}$ concentrations are anthropogenic in nature (Różkowski, 1996; Baścik et al., 2001; Siwek, 2004), attributable to animal husbandry, agriculture and the absence of sewage treatment systems in villages (Galas, 2005). The differences in water quality (Tables 2,3) were clearly reflected in the composition of epilithic and bryophytic diatom assemblages. The high bacterial contamination in springs in villages (Table 2) indicates pollution from wastewater.

Stones are one of the most common substrates in fastflowing waters, but are much rarer in lowland areas. Boulders, cobbles and gravel were virtually absent in 9 of the 36 springs checked preliminary to the study, and at 3 more localities there were no epilithic diatom assemblages present, presumably as a consequence of insufficient light availability. Those springs were excluded from further study. In most springs, however, there were submerged bryophytes. Despite negative interaction-physical and sometimes chemicalbetween epiphytic algae and host macrophytes, epiphytic diatoms do secure a location for growth, improved access to light and shelter from scouring (Burkholder 1996). According to Burkholder (1996), loosely attached epiphytes generally do not exhibit substrate preferences. Moreover, the preferences of epiphytic algae for specific host plants decrease with increasing nutrient concentration (Eminson \& Moss, 1980; Hall \& Smol, 1999). The clearest relationships between hosts and diatom assemblages are known from oligotrophic waters, where nutrient limitation is one of the most important factors governing diatom distributions. In these conditions, macrophytes are an additional nutrient source (Wetzel, 1983) or even the main one (Eminson \& Moss, 1980). Unfortunately, the data on the diatom floras of spring bryophytes are sparse (Cantonati $\&$ Spitale, 2009). Most epilithic and bryophytic diatoms share similar characteristics enabling them to adapt to these habitats, including small size and adaptations enabling adhesion. Some species seemed to prefer certain substrates (e.g. Caloneis fontinalis in submerged bryophytes, Achnanthidium pyrenaicum on stones) but the general response of diatom assemblages as a whole to water chemistry was very similar. The results are in agreement with those from other studies of running waters (Jüttner et al., 1996; Rothfritz et al., 1997; Rott et al., 1998; Potapova \& Charles, 2005) and springs (Cantonati \& Spitale, 2009).

The relatively low species richness in the studied springs corresponds well with results from springs in the Pyrenees (Sabater \& Roca, 1990, 1992) and Alps (Cantonati, 1998; Cantonati \& Spitale, 2009), but could also be related to anthropogenic alteration of spring water quality in that upland, where some factor or set of factors limits the growth of the most sensitive taxa. In some springs, the epilithic diatom assemblages were dominated by the neutrophilous Achnanthidium 
minutissimum, whereas bryophytic samples (Fontinalis antipyretica L.) were dominated by the alkaliphilous Planothidium lanceolatum. The differences might be related to host (bryophytes) photosynthetic processes, as host biological processes drive a rapid increase of $\mathrm{pH}$ (Wetzel, 1983) and precipitation of calcium carbonate (Burkholder, 1996). In addition, Planothidium lanceolatum prefers substrates that provide protection from abrasion (Biggs, 1996), and such conditions can be expected in submerged bryophytes (Cantonati \& Spitale, 2009). Note that although the observed assemblages consisted of common diatoms having up to $96 \%$ relative abundance, of which several probably are habitat generalists; they represented only one-third of the total number of taxa identified in diatom counts. Those findings are in agreement with Townsend \& Gell (2005) who observed the occurrence of common taxa in large numbers on all substrates, whereas taxa unique to a single substrate attained $0.1-2 \%$ relative abundance. In our study, the rest of diatoms (85 taxa) were rare $(<1 \%)$, and their presence varied greatly among springs. Sometimes the more common diatoms also reflected the individual character of the assemblages in certain springs. For example, the spring in Weggrzynów was the only one where Fragilariforma nitzschioides was observed, reaching over $60 \%$ relative abundance. Unlike in springs in the Alps (Cantonati \& Spitale, 2009), we did not find significant differences in species richness or the diversity index $\left(H^{\prime}\right)$ between the epilithic and the bryophytic diatom assemblages.

The general variability of the aquatic environment and especially of total ionic strength is known to play a very important part in determining the distribution of diatoms (Sabater \& Roca, 1990; Soininen, 2007; Cantonati \& Spitale, 2009; Angeli et al., 2010). Potapova \& Charles (2005) demonstrated that the effect of ionic strength is of much greater significance than the type of substrate colonized. According to Hall \& Smol (1999), the diatom assemblages on various substrates become uniform in meso- and eutrophic waters, where nutrient limitation is weak. Our results support this. Changes in diatom assemblages were associated mostly with nutrient concentration, which was higher in springs in or near villages, as reflected in the TDI and SPI indices. Specific conductivity, dissolved oxygen and correlated factors had a strong effect on the structure of the diatom assemblages studied.
The methodological standards of monitoring programs recommend collecting material from stones (Round, 1991, 1993; Kelly et al., 1998), but this community is often absent in slow-flowing waters, and that limits the method to localities from which such material can be sampled. A great number of localities do offer bryophytic material for sampling. In our study, the data from both the epilithic and the bryophytic samples yielded diatom indices (TP, SPI) that reflected differences in water quality between springs, demonstrating that the two substrate types can be sampled for water quality assessment in slowflowing mesotrophic and eutrophic waters.

Acknowledgments The authors acknowledge the valuable suggestions of anonymous reviewers on the manuscript. We highly appreciate the identification of bryophytes by Dr. Beata Cykowska (Institute of Botany PAS) and Michael Jacobs for English correction. The study was partly supported by the Polish Ministry of Science and Higher Education (Grants N304 092834 for 2008-2011 and P04G 09826 for 2004-2007).

Open Access This article is distributed under the terms of the Creative Commons Attribution License which permits any use, distribution, and reproduction in any medium, provided the original author(s) and the source are credited.

\section{References}

Angeli, N., M. Cantonati, D. Spitale \& H. Lange-Bertalot, 2010. A comparison between diatom assemblages in two groups of carbonate, low-altitude springs with different levels of anthropogenic disturbances. Fottea 10: 115-128.

Baścik, M., W. Chełmicki, A. Korska, J. Pociask-Karteczka \& J. Siwek, 2001. Źródła Wyżyny Krakowsko-Wieluńskiej i Miechowskiej. Zmiany w latach 1973-2000. Instytut Geografii i Gospodarki Przestrzennej, Zakład Hydrologii, Uniwersytet Jagielloński, Kraków: 127 pp.

Battegazzore, M., A. Morisi, B. Gallino \& S. Fenoglio, 2004. Environmental quality evaluation of alpine springs in NW Italy using benthic diatoms. Diatom Research 19: 149-165.

Biggs, B. J. F., 1996. Patterns in benthic algae of streams. In Stevenson, R. J., M. L. Bothwell \& R. L. Lowe (eds), Algal Ecology: Freshwater Benthic Ecosystems. Academic Press, San Diego: 31-56.

Burkholder, J., 1996. Interactions of benthic algae with their substrata. In Stevenson, R. H., M. L. Bothwell \& R. L. Lowe (eds), Algal Ecology: Freshwater Benthic Ecosystems. Academic Press, San Diego: 253-297.

Cantonati, M., 1998. Diatom communities of springs in the Southern Alps. Diatom Research 13: 201-220.

Cantonati, M., 2001. The diatom communities of the liverwort Chiloscyphus polyanthus var. rivularis in a mountain spring-fed stream in the Adamello-Brenta Regional Park, Northern Italy. In Jahn, R., J. P., Kociolek, A. Witkowski \& 
P. Compère (eds), Lange-Bertalot-Festschrift. Studies on Diatoms. A.R.G. Gantner Verlag K.G., Ruggell: 353-368.

Cantonati, M. \& D. Spitale, 2009. The role of environmental variables in structuring epiphytic and epilithic diatom assemblages in springs and streams of the Dolomiti Bellunesi National Park (south-eastern Alps). Fundamental and Applied Limnology, Archiv für Hydrobiologie 174: 117-133.

Cantonati, M., R. Gerecke \& E. Bertuzzi, 2006. Springs of the Alps-sensitive ecosystems to environmental change: from biodiversity assessments to long-term studies. Hydrobiologia 562: 59-96.

CEMAGREF, 1982. Etude des Méthodes Biologiques d'Appréciation Quantitative de la Qualité des Eaux. Ministère de l'Agriculture, CEMAGREF, Division Qualité des Eaux, Pêche et Pisciculture, Lyon: 218 pp.

Cox, E. J., 1990. Microdistributional patterns of freshwater diatoms in relation to their use as bioindicators. In Simola, H. (ed.), Proceedings of the Tenth International Diatom Symposium, Joensuu, Finland Aug 28-Sept 2, 1998, Koeltz Scientific Books, Koenigstein: 521-528.

Douglas, B., 1958. The ecology of the attached diatoms and other algae in a small stony stream. Journal of Ecology 46: 295-322.

Dumnicka, E., J. Galas \& P. Koperski, 2007. Benthic invertebrates in karst springs: does substratum or location define communities? International Review of Hydrobiology 92: $452-464$.

Dynowska, I., 1983. Springs within the Upland of CracowWieluń and Miechów. Studia Ośrodka Dokumentacji Fizjograficznej PAN, Kraków 11: 1-130.

Eminson, D. \& B. Moss, 1980. The composition and ecology of periphyton communities in freshwaters. 1 . The influence of host type and external environment on community composition. British Phycological Journal 15: 429-446.

Galas, J., 2005. Human impact on physical and chemical properties of springs from Cracow-Częstochowa upland (southern Poland). Polish Journal of Ecology 53: 329-341.

Hájkova, P., J. Bojková, M. Franková, V. Opravilová, M. Hájek, K. Kintrová \& M. Horsák, 2011. Disentangling the effects of water chemistry and substratum structure on mossdwelling unicellular and multicellular micro-organisms in spring-fens. Journal of Limnology 70 (Suppl. 1): 54-64.

Hall, R. I. \& J. P. Smol, 1999. Diatoms as indicators of lake eutrophication. In Stoermer, E. F. \& J. P. Smol (eds), The Diatoms: Applications for the Environmental and Earth Sciences. Cambridge University Press, Cambridge: 128-168.

Jüttner, I., H. Rothfritz \& S. J. Ormerod, 1996. Diatoms as indicators of river quality in the Nepalese Middle Hills with consideration of the effects of habitat-specific sampling. Freshwater Biology 36: 475-486.

Kelly, M. G. \& B. A. Whitton, 1995. The trophic diatom index: a new index for monitoring eutrophication in rivers. Journal of Applied Phycology 10: 433-444.

Kelly, M. G., A. Cazaubon, E. Coring, A. Dell'Uomo, L. Ector, B. Goldsmith, H. Gausch, J. Hürlimann, A. Jarlman, B. Kawecka, J. Kwandrans, R. Laugaste, E.-A. Lindstrøm, M. Leitao, P. Marvan, J. Padisák, E. Pipp, J. Prygiel, E. Rott, S. Sabater, H. van Dam \& J. Vizinet, 1998. Recommendations for the routine sampling of diatoms for water quality assessments in Europe. Journal of Applied Phycology 10: 215-224.

Lecointe, C., M. Coste \& J. Prygiel, 1993. "Omnidia": software for taxonomy, calculation of diatom indices and inventories management. Hydrobiologia 269-270: 509-513.

Lepš, J. \& P. Šmilauer, 2003. Multivariate Analysis of Ecological Data Using CANOCO. Cambridge University Press, Cambridge.

Potapova, M. \& D. F. Charles, 2005. Choice of substrate in algae-based water-quality assessment. Journal of the North American Benthological Society 24: 415-427.

Rothfritz, H., I. Jüttner \& A. M. Suren, 1997. Epiphytic and epilithic diatom communities along environmental gradients in the Nepalese Himalaya: implications for the assessment of biodiversity and water quality. Archiv für Hydrobiologie 138: 465-482.

Rott, E., C. Duthie \& E. Pipp, 1998. Monitoring organic pollution and eutrophication in the Grand River, Ontario, by means of diatoms. Canadian Journal of Fisheries and Aquatic Sciences 55: 1443-1453.

Round, F. E., 1991. Diatoms in river water-monitoring studies. Journal of Applied Phycology 3: 129-145.

Round, F. E., 1993. A Review and Methods for the Use of Epilithic Diatoms for Detecting and Monitoring Changes in River Water Quality. HMSO, London.

Różkowski, J., 1996. Transformations in chemical composition of karst water in the southern part of the Cracow Upland (Rudawa and Prądnik drainage areas). Prace Naukowe Uniwersytetu Śląskiego w Katowicach nr 1586. Kras i Speleologia, nr spec. 1: 1-106.

Sabater, S. \& J. R. Roca, 1990. Some factors affecting distribution of diatom assemblages in Pyrenean springs. Freshwater Biology 24: 493-507.

Sabater, S. \& J. R. Roca, 1992. Ecological and biogeographical aspects of diatom distribution in Pyrenean springs. British Phycological Journal 27: 203-213.

Sabater, S., S. V. Gregory \& J. R. Sedell, 1998. Community dynamics and metabolism of benthic algae colonizing wood and rock substrata in a forest stream. Journal of Phycology 34: 561-567.

Siwek, J., 2004. Źródła w zlewniach Prądnika, Dłubni i Szreniawy. Naturalne i antropogeniczne uwarunkowania jakości wód. Instytut Geografii i Gospodarki Przestrzennej, Uniwersytet Jagielloński, Kraków: 98 pp.

Soininen, J., 2007. Environmental and spatial control of freshwater diatoms - a review. Diatom Research 22: 473-490.

Stevenson, R. J. \& S. Hashim, 1989. Variation in diatom community structure among habitats in sandy stream. Journal of Phycology 25: 586-678.

Stoermer, E. F. \& J. P. Smol (eds), 1999. The Diatoms: Applications for the Environmental and Earth Sciences. Cambridge University Press, Cambridge.

ter Braak, C. J. F. \& P. Šmilauer, 2002. CANOCO Reference Manual and CanoDraw for Windows User's Guide: Software for Canonical Community Ordination (version 4.5). Microcomputer Power (Ithaca, NY, USA).

Townsend, S. A. \& P. A. Gell, 2005. The role of substrate type on benthic diatom assemblages in the Daly and Roper Rivers of the Australian wet/dry tropics. Hydrobiologia 548: 101-115. 
Werum, M., 2001. Die Kieselalgengesellschaften in Quellen: Abhängigkeit von Geologie und Anthropogener Beeinflussung in Hessen (Bundesrepublik Deutschland), Wiesbaden: 273 pp.

Werum, M. \& H. Lange-Bertalot, 2004. Diatoms in springs from Central Europe and elsewhere under the influence of hydrogeology and anthropogenic impacts. Iconographia Diatomologica 13: 1-417.

Wetzel, R. G., 1983. Attached algal-substrata interactions: fact or myth, and when and how? In Wetzel, R. G. (ed.), Periphyton of Freshwater Ecosystems. Developments in
Hydrobiology, Vol. 17. Dr. W. Junk Publishers, Kluwer, Dordrecht: 207-215.

Wojtal, A. \& Ł. Sobczyk, 2006. Epilithic diatom assemblages on stones of different size. Verhandlungen der Internationalen Vereinigung für Theoretische und Angewandte Limnologie 29: 1657-1659.

Wojtal, A. Z., A. Witkowski \& B. Scharf, 2009. An approach to the recent environmental history of Pilica Piaski spring (southern Poland) using diatoms. Hydrobiologia 631: 267-277. 